\title{
VERBAL AND NON-VERBAL COMPONENT OF EMOTIVENESS IN POLITICAL DISCOURSE: TRANSLATION ASPECT
}

\author{
Kulish V.S., Ph.D. in Philology, Senior Lecturer \\ ORCID ID: https://orcid.org/0000-0002-8283-7431 \\ Sumy State University, \\ 2, Rymskogo-Korsakova St., Sumy, 40007, Ukraine \\ E-mail: kulish.vladislava@ukr.net;
}

Niemtseva Ya. M., student

E-mail: yasya.nem@gmail.com

The article deals with the question of creating the emotiveness in political message with verbal and non-verbal means. It points out the specific features of creative emotive effect by politicians. These features realize the high level of emotiveness in the communicants' reaction. The paper is aimed at analyzing verbal and non-verbal component of emotiveness according to the translation aspect, ways of rendering emotions by means of different languages. The aim of the research implies conducting the detailed analysis of the conveyance of the linguistic and extralinguistic means of expressivity in the Ukrainian translations. As a result the features of emotions transmission on verbal and non-verbal levels were found, their functions in formation the emotive effect of a political message were determined and the ways of its rendering by means of correlated languages were distinguished.

Key words: political discourse, emotiveness, verbal and non-verbal components, emotions. https://doi.org/10.21272/Ftrk.2018.10(4)-5

Problem statement. Political communication has played an important role in the life of society and country at all times. Political discourse is the main expression of the relationship between man and society. The public purpose of political discourse is to convince recipients of the need for «politically correct» actions and estimations. The category of emotiveness or expressivity is one of the main category which helps to accomplish this purpose. Modern linguists focus on the speech activity of man, the features of communicative processes and the individual communicative behavior of the speaker, which is a set of verbal and nonverbal components in close interaction. Therefore, it is important to study verbal and non-verbal means by which emotionality appears in the texts of political direction and other types of political activity taking into account the translation aspect.

Literature review. Many scholars and linguists, both Ukrainian and foreign, studied a political discourse, its categories: V. I. Shakhovskii, M. Edelman, N. V. Danilevska, O. O. Selivanova. Their contribution to this topic is significant. Studying of non-verbal means mainly focus on their functions and interaction with verbal components and on their properties of creating political discourse. The study of non-verbal means of is the key to structuring the acquired knowledge about the phenomena of objective reality. Such linguists as T. O. Anohina, A. D. Belova, I. K. Kobiakova, V. S. Kulish, L. V. Soloshchuc, S. O. Shvachko have worked in the sphere of non-verbal communication. Therefore, the study of the representation of non-verbal means in written communications becomes significant, where non-verbal components are translated into a verbal form that has its own peculiarities of structuring. But the phenomenon of verbalization of non-verbal components has not been studied in detail and needs to be studied in depth.

The aim of the article is to define the main verbal and non-verbal means of expressing emotionality (object of the article) and ways of actualization their linguistic and

(C) Kulish V. S., Niemtseva Ya. M., 2018 
extralinguistic features in political texts (the subject of the article). This aim implies the following tasks of the research:

1) to explicate the notion of emotiveness;

2) to find out the features of emotions transmission on verbal and non-verbal levels;

3 ) to determine their functions in formation the emotive effect of a political message;

4) to explain the ways of its rendering by means of correlated languages.

Discussion. The notion of «discourse» includes the socially accepted ways of seeing and interpreting the world around us, arising from this vision of the people actions and the form of society organization. Political discourse is a class of genres, limited by the social sphere, namely politics. The purpose of political discourse is not to describe but to persuade and awaken the recipient's intentions, to provide the basis for persuasion and to encourage action. That is why the language of political discourse is full of symbols, and the success and effectiveness of politics is determined by the extent to which these symbols are consistent with mass consciousness [1, p. 75]. The politician must be able to touch the desired string in the mind; the statement of the policy should be aimed at «consumers» of political discourse.

The category of emotiveness is an integral part of political discourse. V. I. Shakhovsky confirms that emotiveness is a typical semantic ability of the language to express the emotionality as a fact of the psyche with help of its means, social and individual emotions which are reflected in the semantics of the linguistic units [2, p. 9]. The essence of emotiveness lies in the subjective emotional assessment of the certain events, situations by a person.

As N. V. Danilevska states that, due to the emotional assessment, the rational cognitive actions of the author receive a psychological correction and appear in the text in a more refined, verified version. We can say that the emotional assessment plan acts in relation to the cognitive activity of the author as an additional, but no less important mechanism, which forms the meaning and the text itself [3, p. 32]. Emotiveness in a political discourse also varies from genre to genre. The percentage of emotiveness in political discourse does not depend only on the choice of the genre, but also on the specific discursive events or subjects [4]. Thus, it is essential to investigate not only the language (linguistic features) of political texts but also its environment (extra linguistic peculiarities).

O. O. Selivanova understands the emotiveness in the modern linguistic science as the connotative component in the semantic structure of the linguistic unit, which represents the emotional attitude of the bearers of the language to the designated one [5, p. 248]. The structure of emotiveness and the peculiarities of its linguistic reflection are determined by the specifics of the object reflection - emotions. The components of emotiveness are emotional tone, emotional value, intensity and duration. The category of emotiveness as a cognitive category, which actualization takes place in discourse, is reflected in different language system levels [6, p. 106].

The peculiarities of the perception of information by the subjects of the political discourse lead to the filling of texts by verbal means, which give expressions of emotive colour, reveal a position in the assessment of the phenomena of political life, testify the high level of language culture. Emotion can be expressed in speech explicitly or implicitly. In explicit expression, a neutral one is replaced by another one that emphasizes or reinforces emotion. In the case of implicit use, the effectiveness is derived from the context only.

In the political text emotiveness is actualized with the help of emotionally charged text components - emotionally-based markers [5, p. 151]. In the verbal text of a political message, such emotionogenic markers are connoteme (or, in the terminology of Shakhovskii, emosemes [2, p. 12]) - words that contain the seme connotations of feelings, and word combinations that are carriers of the emotional meaning of the whole statement or as part of the statement. This is precisely the example of explicit expression of the emotional effect in political speeches. 
In their speeches, politicians use words that already have a certain emotional colour and a certain assessment of the situation. Emotional words with a positive or negative evaluation, such as, e.g.: eng.: good, excellent, wonderful, stunning, bad, horrible; ukr.: хороший, відмінниц̆, чудовий, приголомшливий, поганий, паскудний, кепський, жахливий are most commonly used to give a certain emotional effect to their words and to suggest their own opinion to voters, e.g.: the speech by Barack Obama at the Paris summit: I've come here personally, as the leader of the world's largest economy and the secondlargest emitter, to say that the United States of America not only recognize our role in creating this problem, we embrace our responsibility to do something about it [7].

It is evident that, lexeme largest is used twice: for the first time in expressing a positive assessment of its country - the world's largest economy, and the second time for its criticism of the air pollutant - the second-largest emitter. This contrast helps to increase the emotional performance. In turn, in the Ukrainian language, all words with an emotional effect are translated by appropriate Ukrainian words or phrases of the same meaning to preserve the essence and intentions of the politician, e. g.: Я приїхав сюди особисто, як лідер краӥни з найбільшою світовою економікою та найбільшим рівнем забруднення, щцоб сказати, щุо Сполучені Штати Америки не лише визнають свою роль у створенні иієї проблеми, а також беруть на себе відповідальність в її виріменні.

Positive connotation adjectives are often used by Barack Obama when he speaks of America, and negative one for in the description of the terrorist organizations, e. g.: We believe in a generous America, in a compassionate America, in a tolerant America [8]. Mu віримо в щедру Америку, у жалісну Америку, у толерантну Америку. The terrible events in Paris were a terrible and sickening setback. Страшні подіï в Парижі були жахливими і хворобливими невдачами.

Among the emotive verbalizers there are often words that belong to the so-called reduced stylistic tone: colloquialism, dialecticism, sleng, jargon, vulgarism. The use of such words in speech is due to certain pragmatic goals and creates the vividness and visibility of live speech [9, p. 156]. Such words clearly contradict the literary norm, and in this very essence the novelties of their use. Nick Clegg, Deputy Prime Minister said in his speech to the Institute of Government think tank, e. g.: The Government has not been consumed by some sort of almighty row between peaceniks on the one hand and securocrats on the other [10]. Уряд не був поглинутий свого роду всемогутньою суперечкою між прихильниками миру з одного боку та впливовими військовослужбовиями. The translator is forced to resort either to the description or to the corresponding lexical transformation, seeking authenticity of the interpretation to form the emotional effect. That is, the translation offers option, which, in his opinion, is the most successful according to the form and content $[11, \mathrm{p} .45]$.

Another verbal means of expressing emotiveness is the metaphorical formations, the use of stable expressions, phraseologisms for the description of emotions and the identification of emotional and evaluative characteristics, e.g: The internet has opened a Pandora's box of extremism and fury, and the vitriol spills back into real-world politics [12]. Інтернет відкрив скриньку Пандори з екстремізму та люті, $і$ весь потік сарказму виливається назад у реальну політику. This is a big project, and we've only got one shot to get it right. Це великий проект, $i$ у нас $є$ лише один шанс, щоб зробити все правильно. Т人е candidate has continued to stand her ground despite criticism. Кандидат продовжував стояти на своєму не зважаючи на критику. In all of the examples above, phrases and idioms are translated into Ukrainian by absolute or near equivalents. One more significant feature is the adequacy of the translation equivalents of phraseological units, that is objectified by a deep cognitive analysis of the indicated units in the language of the original and the target language [13, p. 244].

Not less important are non-verbal means of communication in political discourse. Nonverbal communication is a sign system used in the communication process and is different from verbal with form and means of detection. With the help of gestures, facial expressions and poses it is possible to understand the truth of the pragmatics of political speeches. 
Nonverbal components also express the attitude of participants in the speech act to each other, the level of communication between the communicant and the recipient. Nonverbal means of communication are marked by situational, dialogical and need a common social and linguistic experience to understand the depth of the referent's content $[14, \mathrm{p} .17]$.

In live speech, nonverbal means of communication contribute to the improvement of communicative perception. In some cases, non-verbal units can serve as a more accurate, expedient, concise, or even the only means of transmitting a speech message. Non-verbal units meet at different stages of communication and increase the emotional and expressive value of the linguistic component, delivering the message's completeness [15, p. 129]. For verbalizing non-verbal means, creative potential is inherent, as the verbal component must preserve semantics and cover the entire spectrum of values of the non-verbal component.

Gestures performed by hands are the oldest form of non-verbal communication. Today hands are perceived to be the most «talkative» part of the body and are used to perform various functions e.g. express wishes, show feelings and symbolize moods. It is known that «raised steeple» (fig. 1, 2) and raised hands and directed toward the audience (fig.3) are a signal of assurance and confidence of the speaker. It is most often used while politicians do the talking. During the process of verbalization it is widespread to describe logically, to explain the formed meaning and the implementation of its typical features. Associations are formed on the basis of the phenomena of objective reality and experience gained while staying in a socio-cultural environment [16, p. 73]. This gesture can be interpret with such words and word combination as with confidence, to assure, certainly, з упевненістю, гарантувати, безсумнівно еtс.

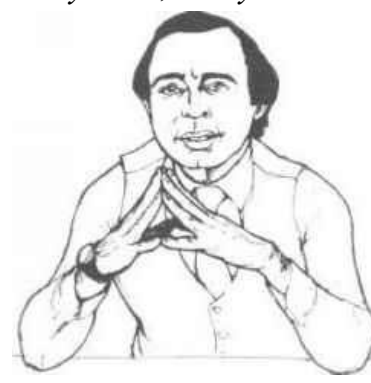

Fig.1

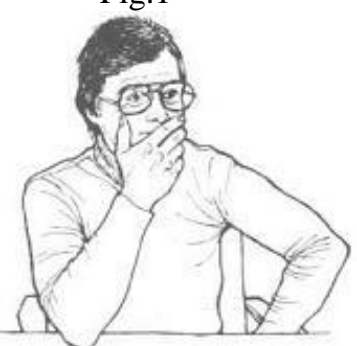

Fig. 4

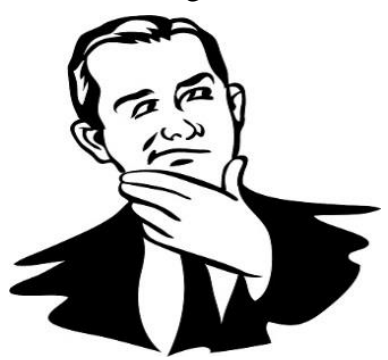

Fig. 6

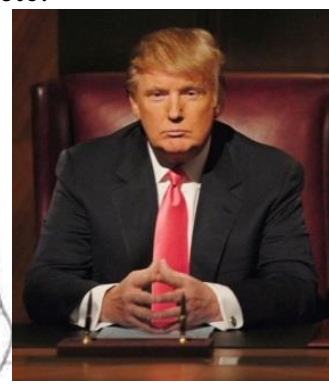

Fig.2

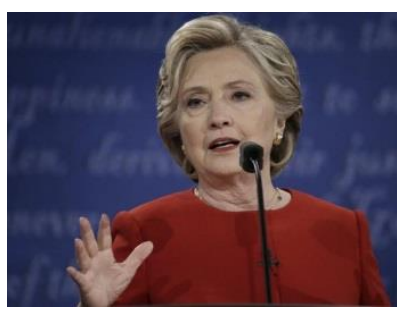

Fig.3

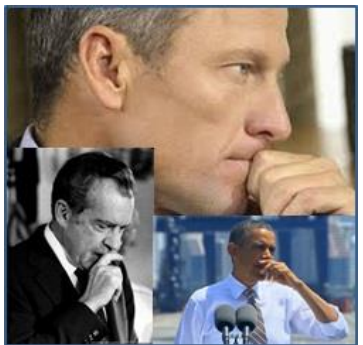

Fig. 5

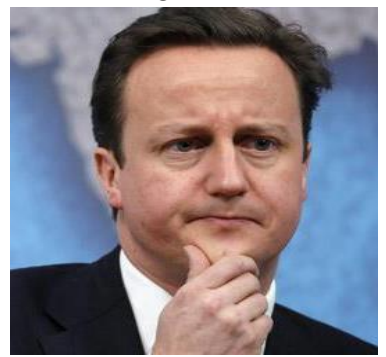

Fig. 7 
Mouth guard gesture (fig. 4, 5) means that the speaker, politician tries to hide the truth, to suppress the deceitful words that are being said. The widespread component of gesture representation is the epithet. Epithets express the communicative intention of a speech act. Such words as, e.g.: eng.: dubious, doubtful, questionable, uncertain, shady, off-color, risky; ukr.: сумнівний, ненадійний, підозрілий, ризикований are used to convey the intentions of the politicians and cast doubt on his words and their truthfulness.

Another gesture is hands on the chin (fig. 6, 7). It means that person is not so confident in his words and has some doubts. It can be verbalized with such words as, e.g.: eng.: ипсеrtain, unsure, unconfident, unclear; ukr.: невпевнений, неясний, невизначений.

The implementation of a successful communicative act can only be achieved through the interaction of verbal and nonverbal components of communication, since nonverbal units, refute language means or replace the linguistic component, as well as regulate the dynamics of the communicative act.

Conclusions. Therefore, the category of emotiveness is an integral part of the successful implementation of political discourse and the fulfillment of its main functions. It can be expressed through a variety of verbal means, such as emotive lexic, phraseological units, etc., as well as through non-verbal means: gestures, facial expressions, etc. Nonverbal communication often carries a more significant content load and affects more the whole process of communication. When translating both verbal and non-verbal political communication it is important to preserve the intentions of the speaker, the emotional effect of his speech.

\section{ВЕРБАЛЬНИЙ ТА НЕВЕРБАЛЬНИЙ КОМПОНЕНТ ЕМОТИВНОСТ В ПОЛТТИЧНОМУ ДИСКУРСІ: ПЕРЕКЛАДАЦЬКИЙ АСПЕКТ}

Куліш В. С., канд. філол. наук,стариий викладач кафедри германскої філології https://orcid.org/0000-0002-8283-7431

Сумський державний університет

вул. Римського-Корсакова 2, м. Суми, 40007, Украӥна

E-mail: kulish.vladislava@ukr.net;

Немцева Я. М., студентка

E-mail: yasya.nem@gmail.com

У статті розглянуто питання актуалізачії емотивності в політичному повідомленні за допомогою коррелячії вербальних та невербальних компонентів. Увага фокусується на реалізації емотивного ефекту на всіх мовних рівнях із залученням лінгвістичних та екстралінгвістичних факторів, щяо впливають на підвищену емотивність реакиії комунікантів. Мета роботи полягає в аналізі вербального та невербального компоненту емотивності в перекладацькому аспекті, способів відтворення емоцій засобами різних мов. Задля досягнення мети дослідження було проведено детальний аналіз передачі лінгвістичних та екстралінгвістичних засобів емотивності в украӥнських перекладах. У результаті було виявлено особливості передачі емоцій на вербальних та невербальних рівнях, було визначено їх функцій у формуванні емочійного ефекту політичного повідомлення та були визначені шляхи їх відтворення за допомогою корелюючих мов. Під час дослідження було встановлено, що категорія емотивності $\epsilon$ невід'ємною складовою та однією з характерних особливостей політичного дискурсу. Вона може виражатись як імпліцитно, так і експлічитно за допомогою вербальних та невербальних засобів. Суть емотивності полягає в суб'єктивній емоичійній оцінці особою певних подій та ситуацій. Особливості сприйняття інформаиії речипієнтами політичного дискурсу призводять до великої кількості лінгвістичних та екстралінгвістичних засобів, щзо виражають емоційне забарвлення тексту. Завдяки вірним засобам вираження емотивності в політичній комунікачії мисленнєві дії автора, політика отримують психологічну кореляцію, постають у тексті у більш відточеному варіанті та ефективніше впливають на реципієнта. Було з'ясовано, що невербальна комунікація несе в собі більше смислове навантаження $і$ більш впливає на весь прочес спілкування. Важливо при перекладі та інтерпретачіi вербальних $i$ невербальних засобів емотивності зберегти наміри мовия та емоційний ефект висловлювання.

Ключові слова: політичний дискурс, емотивність, вербальні та невербальні засоби, емочії. 


\section{ВЕРБАЛЬНЫЙ И НЕВЕРБАЛЬНЫЙ КОМПОНЕНТ ЭМОТИВНОСТИ В ПОЛИТИЧЕСКОМ ДИСКУРСЕ: ПЕРЕВОДЧЕСКИЙ АСПЕКТ}

Кулиш В.С., кандидат филологических наук,

стариий преподаватель кафедры германской филологии,

Сумский государственный университет,

ул. Римского-Корсакова 2, г. Сумы, 40007, Украина

https://orcid.org/0000-0002-8283-7431

E-mail: kulish.vladislava@ukr.net;

Немцева Я. М., студентка

E-mail:yasya.nem@gmail.com

В статье исследуется проблема реализации эмотивности в политической речи с помощью вербальных и невербальных средств. Рассмотрено особенности эмотивного эффекта в речи политиков. Эти особенности обусловливают повыменную эмотивность реакций коммуникантов. Цель исследования состоит в анализе вербального и невербального компонента эмотивности в переводческом аспекте, способов воспроизведения эмоций средствами разных языков. Для достижения цели исследования был осуществлен детальный анализ передачи лингвальных и экстралингвальных компонентов эмотивности в украинских переводах. В результате были обнаружены особенности передачи эмочий на вербальном и невербальном уровнях, были определень их функции в формировании эмочионального эффекта политического сообщения и были обозначены способы их отображения при помощи коррелированных языков.

Ключевые слова: политический дискурс, эмотивность, вербальные и невербальные средства, эмоции.

\section{СПИСОК ВИКОРИСТАНИХ ДЖЕРЕЛ}

1. Edelman M. J. Political language: words that succeed and policies that fail / M. J. Edelman. - New York: Academic Press, 1977. - 166 p.

2. Шаховский В. И. Категоризация эмоций в лексико-семантической системе языка / В. И. Шаховский. Воронеж : Изд-во Воронежского университета, 1987. - 192 с.

3. Данилевская Н. В. К вопросу об экспрессивности научного текста / Н. В. Данилевская // Вестник Пермского университета. Сер.: Росийская и зарубежная филология. - 2012. - Вып. 6 (12). - С. 30-36

4. Political discourse: factor of addressee [Electronic resource] / ed. by Mazayev A. Yu., 2005. - Access mode http://www.ostu.ru/conf/ruslang2005/trend1/ mazaeva.htm - Accessed: 25.10.18

5. Селіванова О. О. Сучасна лінгвістика : термінологічна енциклопедія / О. О. Селіванова. - Полтава Довкілля - К, 2006. - 716 с.

6. Емельянов, Д. Синтаксические и графические средства репрезентации категории эмотивности в англоязычном волонтерском дискурсе / Д. Емельянов; науч. рук. И.К. Кобякова // Русский язык в XX веке: исследования молодых: материалы IV международной научной студенческой конференции / Отв. ред. Е.А. Журавлёва. - Астана : ЕНУ им. Л.Н. Гумилева, 2017. - С. 106-108.

7. The Road to a Paris Climate Deal [Electronic resource] / ed. by The New York Times. - Access mode: https://www.nytimes.com/interactive/projects/cp/climate/ 2015-paris-climate-talk - Accessed: 25.10.18.

8. Obama's re-election speech [Electronic resource] / ed. by BBC News. - Access mode : https://www.bbc.com/news/world-20236369 - Accessed: 25.10 .18

9. Белова А. Д. Лингвистические аспекты аргументации: монография / Алла Дмитриевна Белова. - К. : Логос, 2003. - 300 с.

10. Control orders: Nick Clegg denies 'peaceniks' row [Electronic resource] / ed. by BBC News. - Access mode : https://www.bbc.com/news/uk-politics-1213363 - Accessed: 25.10.18.

11. Куліш, В. С. Інтерпретація стилістично-маркованих номінацій мовчання (на матеріалі англомовного та російського поетичних дискурсів) / В.С. Куліш // Філологічні трактати. - 2012. - Т. 4, № 2. - С.45-49.

12. From Trump to Brexit rhetoric: how today's politicians have got away with words [Electronic resource] / ed by The Guardian. - Access mode : https://www.theguardian.com/books/2016/aug/27/from-trump-to-brexitrhetoric-how-todays-politicians-have-got-away-with-words - Accessed: 25.10.18

13. Швачко С. О. Перекладацькі аспекти фразеологічних одиниць (на матеріалі англійських нумеральних словосполучень) / С. О. Швачко // Вісник Сумського державного університету. Серія Філологічні науки. - 2003. - №4(50). - С. 240-244.

14. Анохіна Т.О. Функціональне навантаження невербальних кодів у різномовних дискурсах / T.O Анохіна // Науковий часопис НПУ імені М.П.Драгоманова. Серія № 9. Сучасні тенденції розвитку мов. Випуск 2. - К. : НПУ імені М. П. Драгоманова, 2007. - С. 12-18

15. Солощук Л. В. Стилістичні аспекти презентації невербальних компонентів комунікації у тексті / Л. В Солощук // Серія «Романо-германська філологія. Методика викладання іноземних мов»: наук.-метод. зб. / ХНУ ім. В.Н. Каразіна. - Харків, 2011. - Вип. 972. - С. 129-134.

16. Мечковская Н. Б. Семиотика: Язык. Природа. Культура / Н. Б. Мечковская. - М. : Издательский центр «Академия», 2004. - 432 с 


\section{REFERENCES}

1. Edelman M. J. (1977) Political language: words that succeed and policies that fail. New York: Academic Press, 1977,166 p

2. Shachovskii V. I. (1977) Categorization of emotions in the lexical-semantic system of language. Voronezh Voronezh University Press, 1977, 166 p.

3. Danilevska N. V. (2012) On the issue of expressiveness of a scientific text. Permian: Visnyk Permian University. Series Russian and foreign philology. № 6 (12). P. 30-36

4. Political discourse: factor of addressee. Retrieved 25.10.2018 from http://www.ostu.ru/conf/ruslang2005/trend1/ mazaeva.html.

5. Selivanova O. O. (2006). Modern linguistics: the terminology encyclopedia. Poltava, Dovkilia, 2006,716 p.

6. Emelyanov D., Kobiakova I. K. (2017). Syntactic and graphical means of representation of emotion category in the English-speaking volunteer discourse. Russian language in the XXI century: research of the young. materials of the IV International Scientific Student Conference. Astana: ENU of L. N. Gumilyov, 2017, P. $106-108$.

7. The Road to a Paris Climate Deal. Retrieved 25.10.2018 from:https://www.nytimes.com/interactive/projects/cp/climate/ 2015-paris-climate-talk

8. Obama's re-election speech. Retrieved 25.10.2018 from: https://www.bbc.com/news/world-20236369.

9. Belova A. D. (2003) Linguistic aspects of argumentation: monograph. Kyiv : Logos, 2003, 300 p.

10. Control orders: Nick Clegg denies 'peaceniks' row. Retrieved 25.10.2018 from:https://www.bbc.com/news/ukpolitics-1213363.

11. Kulish V. S. (2012). Interpretation of stylistic-mark nominate of silence (on materials of English and Russian poetic discourses). Filologichni Traktaty, T. 4, № 2, P.45-49. Retrieved http://tractatus.sumdu.edu.ua/en/kulish-v-s-interpretatsiya-stilistichno-markovanih-nominatsiy-movchannyana-materiali-anglomovnogo-ta-rosiyskogo-poetichnih-diskursiv/

12. From Trump to Brexit rhetoric: how today's politicians have got away with words. Retrieved 25.10 .2018 from: https://www.theguardian.com/books/2016/aug/27/from-trump-to-brexit-rhetoric-how-todayspoliticians-have-got-away-with-words.

13. Shvachko, S. O. (2003) Translation aspects of phraseological units (based on the material of English numerical phrases). Visnk of the Sumy State University. Series Philology [Visnik Sums'kogo derzavnogo $\begin{array}{llllll}\text { universitetu. Seria } & \text { Filologiya]. } & \text { № } & 4(50), & \text { P. }\end{array}$ from: http://essuir.sumdu.edu.ua/handle/123456789/1486

14. Anohina T. O. (2007) Functional load of non-verbal codes in multilingual discourses. Scientific journal of the M. P. Drahomanov NPU. Series № 9. Modern trends in the development of languages. Issue 2. Kyiv: N. P. Drahomanov NPU, 2007, P.12-18.

15. Soloshchuk L. V. (2011) Stylistic aspects of the presentation of non-verbal communication components in the text. Charkiv: Series «Romano-Germanic Philology. Methodology of teaching foreign languages»: sciencemethod. collection / KhNU V. N. Karazin № 972, 2011, P. 129-134.

16. Mechkovskaya N. B. (2004) Semiotics: Language. Nature. Culture. Moskow: Publishing Center «Academia», 2004, 432 p.

Received: 06 October, 2018. 